\section{THIRTEENTH INTERNATIONAL HORTICULTURAL CONGRESS}

$T$

HE thirteenth International Horticultural Congress was held in London during September 8-15. It was opened on the morning of September 8 by Sir Thomas Dugdale, the Minister of Agriculture and Fisheries. Lord Aberconway, president of the Congress, and Dr. H. V. Taylor, vice-president and chairman of the National Organizing Committee, also spoke. Lord Aberconway particularly stressed the importance for horticulturists as well as for botanists of the stability of names of the more widely grown plants, and meetings of the International Committee on Horticultural Nomenclature and Registration were held every day throughout the Congress.

This was the first International Horticultural Congress since the one in Berlin in 1938 and, as befitted the times, the main theme of the Congress was the discussion of methods by which new developments in horticulture, plant breeding and the control of pests and diseases have raised and can raise further the world production of food and other economic crops. Each morning there were general lectures which were considered as being of wide importance to horticulturists, while in the afternoon the Congress divided into seven sections dealing with fruit growing, vegetable growing, ornamental plant growing, plant breeding, environmental control, seeds and tropical and sub-tropical horticulture, respectively. As far as possible, summaries of the general lectures and full copies of the papers prepared for sectional meetings were made available in advance to Congress members.

Throughout the Congress the reliance of modern horticulture on scientific research was stressed, particularly in the fields of genetics and cytology and plant physiology.

The role of climate and its influence on plant growth was discussed by Dr. F. W. Went, of the United States. In particular he described the modifications in various factors, such as temperature and humidity, which can be obtained by artificial means such as cultivation in greenhouses or against walls, and their effect on the plants cultivated, and was able to bring under a scientific scrutiny many traditional horticultural methods. Other aspects of this problem were discussed by Prof. Pierre Chouard, of France, and Dr. J. W. M. Roodenburg, of the Netherlands. Prof. G. E. Blackman, of Oxford, showed his methods for making an analysis of the effects of seasonal light intensity and temperature on the growth of plants in the vegetative phase with special reference to the English bluebell, Scilla non-scripta (Endymion nonscriptus), and the effects of shading on growth and development. He was able to show that for each plant it is possible to estimate the light intensity at which growth will be optimal. The control of photoperiodicity by practical methods and the effect of artificial lamps on growth were discussed by several speakers. Dr. J. W. M. Roodenburg showed that the low-tension neon lamp giving a red-orange light and the ordinary incandescent lamp were effective in increasing growth in periods of low light intensity such as the shorter days of winter. Radiation from the red end of the spectrum appears to be effective in promoting the flowering of many long-day plants such as sugar-beet, but retards flowering in the case of short-day plants. Prof. F. G. Gregory also gave a most interesting paper as a general background to recent physiological research in the control of growth and reproduction in plants by environmental factors.

Prof. K. Mather, of Birmingham, in a general lecture on the relation of genetics to plant breeding, gave some pointers for the production of new horticultural crop plants through polyploidy and other factors, such as the variation induced by the use of ionizing radiations like $\mathrm{X}$-rays and by certain chemicals. He confessed, however, that we still have no clue as to how to produce direct mutations, or even as to whether this is possible. The importance of heterosis or hybrid-vigour was stressed by several other speakers, particularly by Dr. Gordon Haskell, and the effects were well shown by the hybrid strains of onion produced by Dr. H. A. Jones, of Beltsville, United States. In this section Dr. S. L. Emsweller, also of Beltsville, read a fascinating paper on developments in plant breeding due to the use of colchicine, a substance which, by inducing polyploidy, has opened the door to many interesting new combinations of genes. The effects of polyploidy on sterility were mentioned by several speakers, and this is obviously a subject which requires further study.

The section on fruit growing was a strong one, and Prof. T. Wallace, of Long Ashton, Bristol, gave an introductory general lecture entitled "Some Aspects of the Mineral Nutrition of Horticultural Plants". Prof. Wallace has made a special study of the effects of deficiencies of mineral trace elements in the cultivation of fruit, and this paper gave a valuable summary of a field of obvious interest and importance to the practical grower and one in which, once the correct diagnosis has been made, the cure can be effected with reasonable certainty. The work of the East Malling Research Station in Kent in standardizing root stocks for apples and pears is now well known and part of the common horticultural practice of the fruit grower; but Dr. Beryl Beakbane described some of the scientific reasons behind the effects of particular rootstocks in a paper on the anatomical structure in relation to rootstock behaviour, while Mr. A. P. Preston, also of East Malling, discussed some new apple rootstocks. The proportion of bark, that is tissues outside the cambium, to wood in the lateral roots of clonal rootstocks has been found to be related to the effect of the rootstock on the size of tree at maturity, rootstocks with a large amount of bark being the most dwarfing. Mr. Preston described a new series of apple rootstocks resistant to woolly aphid. These were bred jointly at East Malling and the John Innes Horticultural Institution, and more than twenty new rootstocks have been bred and selected out of 3,758 seedlings. Damage from spring frosts has proved one of the most difficult problems with which the grower of fruit in Britain has to contend. Dr. W. S. Rogers, also of East Malling, described the new technique of continuous water sprinkling for protection from frost, the main heating effect coming from the release of the latent heat of freezing, 80 calories per gram, as the water turns to ice. A precipitation rate of $6 \mathrm{~mm}$. per hour was found to be the most effective and would protect most fruits from a temperature of $21 \cdot 5^{\circ} \mathrm{F}$. In this section one of the most interesting papers was given by Prof. H. B. Tukey, of the United States, in which he described the uptake of nutrients of the leaves and bark of fruit trees and the use of radioactive isotopes for following the nutrients through the tree. This treatment was shown to be effective also in winter when the tree appeared dormant. 
In a combined session on plant diseases and purity of stocks, Mr. W. C. Moore stressed very strongly the importance of ensuring really healthy plant material before it is moved from country to country. The introduction of major pests with plant material is unfortunately only too well known and common an experience. Virus diseases are one of the most difficult problems that horticulturists now have to face, and in his paper on the serological diagnosis of plant diseases caused by virus, which he supported with a film, Prof. E. van Slogteren, of the Netherlands, showed how many virus diseases can at any rate be diagnosed by serological methods, a diagnosis which is independent of the symptoms of the plant.

A paper of great interest on the use of 'Krilium' as a soil conditioner, by Dr. A. J. Lloyd and Dr. C. E. Morgan, of Monsanto Chemicals, Ltd., was presented in this session, and a film was shown demonstrating the power of 'Krilium' to retain a crumbly. soil structure and for the treated soil to retain drops of water without disintegrating. 'Krilium' was described by the authors as "a new synthetic polymeric electrolyte of a resin type, which by reason of its high anion potential, possesses large numbers of reactive groups in the molecule". It is understood that tests are proceeding in Great Britain, and it is to be hoped that soon this material, which is already on the market in the United States, will also be available in Britain.

In a Congress to which more than a hundred different papers were presented by speakers from twenty-seven different countries, it is obviously impossible to do more than touch on a few of the aspects of the very varied mass of material which was available. The report of the Congress will be published through the Royal Horticultural Society, Vincent Square, London, S.W.I, in due course.

In the field of the nomenclature of horticultural plants, a revised International Code was worked out during the Congress and will shortly be published as an interim code prior to submission to the next Horticultural Congress, which it is anticipated will be held in Holland in 1955 or 1956. The Congress also laid great stress on the importance of the registration of the names of cultivated varieties, and in a resolution recommended that an International Registration Authority should be set up as soon as practicable for each genus or group of genera in which cultivated varieties are numerous. The Congress also passed unanimously two resolutions on nomenclature for transmission to the next International Rotanical Congress. It put on record that it was "strongly of the opinion that the interest of increased stability in the nomenclature of cultivated plants would be served by incorporation into the International Code of Botanical Nomenclature of the proposals for Nomina Specifica Rejicienda set out in Taxon I, No. 5 (1952) and urged their adoption at the next International Botanical Congress". It also recommended in a resolution that any provision of this nature should "allow for the rejection of certain earlier homonyms as well as earlier synonyms, and while appreciating the technical difficulties involved, urged the appropriate botanical authorities to make every effort to overcome them". Mr. J. S. L. Gilmour, director of the Cambridge Botanic Garden, was appointed chairman of the International Committee for the Nomenclature of Cultivated Plants.
Other resolutions of the Congress were passed (1) in favour of the establishment of a horticultural bureau in the Food and Agriculture Organization; (2) in support of the recommendations of the International Plant Protection Convention and for increased facilities for the exchange of experimental material between country and country ; (3) in support of the encouragement of research into the fundamental problems of plant physiology ; and (4) for the setting up of a small working party for considering an international method for recording light values on the lines of the Dutch Committee.

Patrick M. Synge

\section{CHEMICAL RESEARCH LABORATORY, TEDDINGTON OPEN DAYS}

FOR the sixth year in succession the Chemical Research Laboratory, Teddington, of the Department of Scientific and Industrial Research, held a series of open days to which the director invited representatives of industry, universities and government departments. This year the open days were during September 23-26, and the attendance at all sessions indicated that there is no slackening of interest in this annual event.

A special feature this year was the new radiochemical building which has been specially designed and constructed, under the supervision of the Ministry of Works, for work with radioactive materials. It incorporates many modern features which make it one of the finest of its kind in Great Britain both for work with radioactive materials and for general chemical research. This building, with its associated pump house and tank farm, occupies an area of some twelve thousand square foet sitéd about a hundred yards from the main Laboratory block and is constructed of red brick with stone facing to conform to other buildings in the area. It comprises administrative offices, laboratories, plant room and service void, and pump house and tank farm. The administrative offices form a single-story section near the main entrance to the building and comprise an entrance hall, offices, conference room (also used as staff room), and cloakrooms which are provided with special facilities for changing and washing.

The main part of the building consists of two large laboratories and a number of smaller rooms divided, in part, by a central passage. Immediately beyond the cloakrooms and on one side of the passage are two laboratories concerned with research on the application of ion-exchange resins to the separation of metals. In these rooms an exhibit showed the development of a method for separating gold from other metals, such as iron, copper, silver, nickel, cobalt and zinc, in cyanide solution by an anionexchanger. In this process, gold is removed from the resin by eluting with a mixture of acetone and hydrochloric acid. The other metals are eluted with aqueous solutions of salts such as sodium cyanide and potassium thiocyanate.

On the opposite side of the passage from the foregoing laboratories is a suite of rooms dealing with the measurement of radioactivity and allied topics. These laboratories comprise a counting room completely screened from electrical interference, a main 